\title{
Introduction: the ABCs of women's entrepreneurial identity - aspirations, behaviors and confidence
}

\author{
Patricia G. Greene and Candida G. Brush
}

I am not one and simple, but complex and many. (Virginia Woolf, 1992: The Waves)

Who am I? This existential question has been central to philosophical pondering since the actual beginning of philosophy. It is largely a question of personal meaning, and one to which early philosophers brought different ideas. Descartes built on Plato, purporting that the soul is the answer to personal identity. Later, John Locke disagreed, maintaining that continuity is the primary issue. His approach was that one starts with a tabula rasa and is subsequently shaped by experience, sensations, reflections, and so on. More recently, research regarding identity has focused on the social aspects, 'Who am I?' in reference to something else: groups (Tajfel, 1978; Tafjel and Turner, 1979) or roles (Stryker, 1980; Stryker and Serpe, 2012).

Our goal for this book is to use a concept of identity to explore ideas related to entrepreneurial identity for women and their businesses. We believe this is important for two reasons. First, the concept of an entrepreneur has historically been that of a male, and in essence the role and identity are masculine in image and expected behavior (Bird and Brush, 2002). Second, the bulk of current research on entrepreneurship generally, and on the topic of identity and individual aspects of entrepreneurs, focuses predominantly on male samples. Some estimate that only 10 percent of all research in entrepreneurship includes or studies women (Jennings and Brush, 2013). This suggests that both practically and theoretically there is reason to examine entrepreneurial identity for women and their businesses.

However, given the very broad nature and long history of investigation of identity, we overlay another set of entrepreneurial concepts to provide insight into women's entrepreneurship. We focus this volume (and associated articles) on three concepts - aspirations, behaviors and confidence - each related to identity in that they provide insights into our understanding of women entrepreneurs, their ventures and experiences. We consider aspirations to explore what women want to create or achieve, behaviors to look at how they create and grow businesses, and confidence to relate to the 'why', considered as their trust in themselves and their degree of self-assurance. Together, these concepts shape and enhance a woman's 
identity in the entrepreneurial process. We are joined in this endeavor by a set of authors who are also curious about identity and women's entrepreneurship, and the relationship to aspirations, behaviors and/or confidence.

The pathway for our exploratory journey is to first quite briefly review the notion of identity in general, what it is and how it is constructed, and then consider the linkages between identity, aspirations, behavior and confidence. We then move to entrepreneurial identity and its particular construction, and finally we explore women's entrepreneurial identity. This chapter then provides an overview of each of the chapters in this volume regarding women's entrepreneurial identity and aspirations, behaviors and confidence. We conclude with thoughts on what we have learned through this process, and suggestions for future research.

\section{The question of identity}

Identity as a topic of inquiry is found in many social science disciplines, with conceptual differences readily evident both across and within these disciplines (Stryker and Burke, 2000). However, the main approaches include personal identity, social identity theory (SIT) (Tajfel, 1982) and identity theory (Stryker and Serpe, 2012).

\section{Personal identity}

Personal identity generally includes an individual's attributes and traits, values, beliefs and bodily attributes, and in some considerations, also their interests and competencies (Ashforth and Mael, 1989). While it would seem that the personal at this level would be the starting point for an identity, it can also be considered as more of an end, or integrative mechanism, coalescing aspects of group memberships and/or roles (Markus and Nurius, 1986). Personal identity is also described as under-researched and, we propose more specifically, undertheorized in entrepreneurship. When thinking of the relationship to the field of entrepreneurship in which attributes and traits were an early point of fascination, we have seen the field largely move beyond these two concepts to other types of questions.

\section{Social identity theory}

On the other hand, social identity theory (SIT) is a fairly well-researched concept that looks at 'the group in the individual' (Hogg and Abrams, 1988: 3). As such, SIT is a social-psychological perspective which focuses on social categories. These categories are defined by categorization schemas which are determined through what are seen as the 'prototypical characteristics' of the group (Ashford and Mael, 1989; Turner, 1985). The groups may be based on demographic characteristics such as race, gender or age. They may also be based on affiliations such as political parties or religious denominations, and may be perceived positively or negatively in relation to another group (Tajfel, 1982; Hogg et al., 1995). 
The purpose of the group classification is primarily to cognitively segment and thus provide order to one's social environment, thereby providing a means of adopting a self-definition while also providing a systematic means of defining others (Ashforth and Mael, 1989). Personal attributes are often more consistent, while social identities can be more dynamic as people move in and out of different groups; for example, move into a different age bracket or stage of life, or change political party. How social identities are perceived can also be dynamic, changing positively or negatively in relation or reaction to any particular group (Hogg et al., 1995; Brush and Gale, 2014).

\section{Identity theory}

Role-based identities (mother, architect, entrepreneur, and so on) are at the core of identity theory (Hogg et al., 1995; Stryker, 1987; Brush and Gale, 2014), a focus which perhaps more readily accounts for changes in identities (for example, bachelor to husband, or manager to entrepreneur) as individuals change personal identity characteristics (such as competencies) and also make decisions about relationships, behaviors, occupations, and so on. Given that we all hold many roles, and therefore we all belong to a number of groups, each of us has multiple, and potentially overlapping, identities, related to those roles we enact (Meister et al., 2014; Burke and Reitzes, 1991). This approach again presents identities as cognitive schemas, built from comparisons with expectations, specifically the perception of expectations held for each role (Stryker and Burke, 2000). People generally try to enact their roles in modes and behaviors deemed socially appropriate for specific roles, while valuing different roles in potentially different ways and for situationally different contexts (Adler and Adler, 1987; Schneider et al., 1971; Brush and Gale, 2014).

In the management and business literature, work-related identity is an important element of a personal or social identity. Merton (1957) defines roles as social positions that carry expectations for behaviors and obligations to other actors, ideally to positively affect both the individual and the organization (Brown, 1979; Hall et al., 1970; Ashforth and Mael, 1989). At the same time, within organizational behavior, social identity can be derived from that organization as well as sub-organizational levels, with an outcome, of course, of multiple identities (see Ashforth and Mael, 1989). Not only does the individual derive a social identity from the organization, but also the work role that a person holds can guide their action (McCall and Simmons, 1978). At the same time, while a work role will guide action, the role identity becomes individualized by the role occupant's interpretation of that role (Ibarra, 1999).

\section{Identity construction and durability}

Because our interest in identity is prompted by questions of how individuals become entrepreneurs, or entrepreneurial, this begs the question of how identity is created or constructed, and how durable it is over time. Identity construction takes place 
through a complex interplay of cognitive, affective and social interactions that are contextualized (Marková, 1987); identity motives, pressures that move us toward certain identity states and away from others, help to guide identity construction (Breakwell, 1988). The motives themselves may vary through time or situation and may include things such as affinities for self-esteem, continuity, distinctiveness, as well as belonging or a sense of meaningfulness (Vignoles et al., 2006). Identity might be considered both as category-based and role-based (for example, a woman entrepreneur or an African-American student). However, one identity might be more salient in different situations, such as a classroom, a social group meeting or other context (Ashforth et al., 200o) such as a professional environment. While identity construction might start with personal aspects and group membership, the identity outcome is also largely dependent on the prioritization of those identity inputs, or the saliency of each individual part, which is considered to be both mutable and dynamic in reaction to social environments (Meister et al., 2014).

One way to look at saliency is through an individual's level of commitment to the identity. 'Commitment shapes identity salience shapes role choice behavior' (Mead, in Stryker and Burke, 2000, p. 286). In other words, commitment to a particular role identity is high if people perceive that many of their important social relationships are predicated on occupancy of that role (Stryker and Stratham, 1985). The more strongly a person is committed to an identity, the greater the level of identity salience (Stryker, 1980), measured by what it costs to lose important relationships to others if that identity were closed (Stryker and Burke, 200o).

Overall, ongoing 'identity work', indeed 'conscious identity work', will include not only forming, but also maintaining upkeep through repairs and revisions (Svengingsson and Alvesson, 2003: 1165). The development of narrative has been presented as a tool for identity construction (Ibarra and Barbulescu, 2010). The approach views identity as 'the internalized and evolving story that results from a person's selective appropriate of past, present, and future' (McAdams, 1999: 486, in Ibarra and Barbulescu, 2010: 135). As such, narratives are the means of capturing self-schemas and meanings associated with individuals as they interact with others.

\section{Entrepreneurial identity}

In one of the earliest specific works on entrepreneurial identity, Stanworth and Curran (1976) explicitly drew forth the difference between their analysis of entrepreneurial roles as related to self-definition and the ubiquitous earlier perspective of an indelible personality type in place before the undertaking of any entrepreneurial roles. Instead, Stanworth and Curran acknowledge the contribution of social aspects in building the identity, and posit three latent social identities as role components: artisan, classical entrepreneur and the manager. Since then a variety of different types of entrepreneurial identities and typologies have been proposed in the entrepreneurship literature (Woo et al., 1991; Westhead and Wright, 1998; Vesalainen and Pihkala, 2000; Fauchart and Gruber, 2011), along with a variety of 
definitions for the overarching entrepreneurial identity (for a summary see Crosina, Chapter 5 in this volume).

This body of research has grown significantly and has evolved from the idea of typologies and the investigation of stereotypes to a deeper, and also broader, study of entrepreneurial identity, including the contribution of discourse and narrative as a methodology (Fletcher, 2007; Foss, 2004; Johansson, 2004; Warren, 2004; Downing, 2005; Berglund, 2008; Down and Warren, 2008; Phillips et al., 2013), passion (Cardon et al., 2009; Chen et al., 2009; Murnieks et al., 2014) and persistence (Hoang and Gimeno, 2010), industry (Vesala et al., 2007; Lindgren and Packendorff, 2008; Jain et al., 2009), family business (Shepherd and Haynie, 2009; Watson, 2009), type of company (Miller et al., 2011) and geographic region and/or culture (Erogul and McCrohan, 2008; Farmer and Kung-Mcintyre, 2008; Kikooma, 2011; Gill and Larson, 2014). Two more recent compelling paths have included the pursuit of understanding any potential differences related to identities within a defined arena of social entrepreneurship (Light, 2005; Jones et al., 2008), and the role of entrepreneurship education in shaping entrepreneurial identities (Edwards and Muir, 2012; Vanevenhoven and Liguori, 2013; Hytti and Heinonen, 2013; Donnellon et al., 2014).

In looking across the existing research in entrepreneurial identity, we see that there are connections to organizational identity in three ways: distinctiveness, or what is meant by a specifically entrepreneurial identity; centrality, which we connect with salience; and endurance, which we connect with construction and/or durability (Kreiner et al., 2015).

The idea that entrepreneurs are somehow distinct and different represents a central theme in the entrepreneurship literature (e.g., Baker and Nelson, 2005), and to identify oneself as an entrepreneur provides individuals with the opportunity to satisfy their need for distinctiveness, while recognizing a potential imbalance with a need for belonging (Shepherd and Haynie, 2009; Tajfel and Turner, 1986; Turner, 1985). In much of the work related to identity, this is generally ascribed to be through membership in an organization, one which provides an identity that is intended to have positive effects for both the individual and the organization (Brown, 1969; Hall et al., 1970; Lee, 1971, in Ashforth and Mael, 1989: 20). We posit that the business organization itself is of interest in a quite different way to those acting as entrepreneurs, especially those in the process of creating an organization.

Not only may the organization not yet exist, but also other groups potentially contributing to the work identity, such as 'work group, department, union, lunch group, age cohort, fast-track group, and so on' (Ashforth and Mael, 1989: 22), also either do not exist or at best are emerging. Further, the entrepreneur is often in the process of creating the new organization, and therefore simultaneously creating a role identity as the entrepreneur, and the organizational identity, which is often manifested in the culture of the emerging venture (Gartner and Brush, 2007). More specifically, the entrepreneurs rely on their tacit knowledge, experience and social 
contacts to build the systems, boundaries and overall identity of the emerging organization. In this process the entrepreneur may actually try on different identities, as the organizational and entrepreneurial identities are shaped simultaneously.

Distinctiveness must be considered not only in differentiating between an entrepreneurial identity and another work identity, but also within types or approaches to entrepreneurship. For instance, an entrepreneur opening a food truck business may theoretically hold a different entrepreneurial identity than one pursuing venture capital for a technology venture. These differences may be predicated on a number of bases, including motivation and previous experience, role models, funding needs and sources, team structure, common obstacles, networks, and definitions of successful outcomes.

The issue of centrality is also critical, raising the question of the saliency of the entrepreneurial identity in the personal identity hierarchy. This question will be particularly relevant as we later move into the question of women's entrepreneurial identity (Kreiner et al., 2015). Recognizing that there is not an entrepreneurial identity (Stanworth and Curran, 1976), we are intrigued by the situation of the entrepreneurial identity as one of the multiple and overlapping identities that make up any person, as well as the effect of social interactions in that process (Meister et al., 2014). Like Meister et al. (2014), we are especially intrigued by the saliency question, including the movement from affirmation or self-acceptance to validation (the need for others to recognize that identity).

And finally, we consider the construction, adoption and endurance of an entrepreneurial identity, looked at from a diachronic perspective of how the identity changes over time. Some will adopt the identity of entrepreneur from the moment they have a concept, while some may not consider themselves entrepreneurs until others suggest that they are becoming entrepreneurs, and they therefore may then adopt the identity. But how durable is the identity? In other words, when does a person gain an entrepreneurial identity, how does it last, and how or when might a person stop identifying as an entrepreneur? While the category of nascent entrepreneur has been established (Shaver et al., 2001), the question of when one might no longer be 'an entrepreneur' remains.

Drawing from the career development literature, as an individual engages in activities to start and launch a venture, their identity is somewhat malleable and impressionable. But as they gain experience that solidifies their self-concept as an entrepreneur, their identity develops and the narrative becomes more focused and clarified (Carlsen, 2006; Hall, 2002). Again, much of this depends on the selfidentification of the roles that must be filled depending on the perception of being entrepreneurial. 


\section{Identity and aspirations, behavior and confidence}

\section{Identity and aspirations}

Our use of aspirations follows Farmer et al.'s (2011: 245) description as 'longings, aims, or ambitions', while we posit that 'aspiration' is actually an underdefined and under-researched concept throughout entrepreneurship. Two exceptions exist: the aspiration to start a business, which can be seen as the assumption of the identity of an entrepreneur (Farmer et al., 2011); and aspirations for a high-growth venture (Cassar, 2007). What is needed is a more articulated approach to investigating and/ or describing what an individual really wants to accomplish through their entrepreneurial behaviors. Currently, specificity about the overall value desired to be created through the behaviors generally remains largely amorphous.

The question of aspirations is one that is also too often missed in economic development programs. Policy approaches generally adopt 'three stylized facts' (Hessels et al., 2008):

1. The entrepreneur (as business owner) enhances economic growth (Carree and Thurik, 2003).

2. ' $[\mathrm{H}] \mathrm{i}$-growth firms contribute more to economic growth than small, new firms' (Hessels et al., 2008).

3. There is currently little research on growth aspirations within the diversity of entrepreneurs.

We also question the assumption from an economic development perspective that business growth is always good and desirable.

In fact, the use of the term 'aspiration' itself is in question. While the term 'aspiration' is occasionally used interchangeably with 'goal', 'growth ambitions' (Krueger and Carsrud, 1993) or 'objective', as a cognitive measure it can also be seen as having possible ties to entrepreneurial motivation, achievement motivation, as well as Ajzen's (1991) theory of planned behavior (Krueger and Carsrud, 1993). Simply put, aspirations relate to what you want to accomplish; motivations put forth why you want to accomplish something. We also differentiate between aspirations (what you want to happen) and expectations (what you think is going to happen) (Manolova et al., 2012; Hessels et al., 2008).

The stage of business creation and development does play a role in the relationship between identity and entrepreneurial aspirations. At the nascent stage, the desired entrepreneurial identity (possible self) serving as the foundation for the work identity can be seen to guide both thoughts and behaviors (Cross and Markus, 1994; Markus and Nurius, 1986; Farmer et al., 2011). The identity aspired to as an entrepreneur would depend on the individuals' perspectives on the definition and required roles of an entrepreneur. One way to consider this is to look at the relationship between business accomplishments and entrepreneurial self-image (Verheul et al., 2005). (These authors also added a consideration of gender which 
Table 1.1 Typology of entrepreneurial identities

\begin{tabular}{ll}
\hline Name/type & Entrepreneurial activity \\
\hline Starter & Enters an independent business by creating a new one \\
Acquirer & Enters an independent business by acquiring an ongoing concern \\
Runner & Manages a small to medium-sized business beyond start-up \\
Take-off artist & Steers a company into a high-growth trajectory \\
Turnaround artist & Saves a failing company \\
Innovator & Makes something new happen that is not a company \\
Champion & Supports an innovator \\
Intrepreneur & Takes initiative for business unit creation inside an established business \\
Industry captain & Runs a big business \\
Mumpreneur & A woman running a business and caring for children simultaneously, bal- \\
& ancing work and life \\
Social entrepreneur & An entrepreneur with innovative solutions to society's most pressing \\
& problems \\
\hline
\end{tabular}

Source: Adapted from K.H. Vesper, in Verheul et al. (2005), Neck et al. (2009), Nel et al. (2010).

will be reviewed in the next section of this chapter.) We added to these authors' use of Vesper's (1999) entrepreneurial typology to include additional potential entrepreneurial identities which may impact aspirations, and vice versa. Table 1.1 summarizes a typology of entrepreneurial identities.

One helpful exception is seen in the work of Kolvereid (1992), where he recognizes that 'most firms are born small and stay small' and finds only a weak relationship between motives to start the business and growth aspirations. Patterns in his findings suggest that 'entrepreneurs with no growth aspirations have a tendency to be driven by independence and opportunism, entrepreneurs with revenue growth aspirations by welfare and tax considerations, and entrepreneurs with both revenue and employment growth aspirations by their achievement motive'. However, he declares these findings to be weak, concluding that overall aspirations are not found to be significantly affected by 'experience, sex, location, or firm size by employee'. Other work finds that nascent entrepreneurs will be motivated to grow if they believe that the efforts expended will lead to the outcome they seek (Douglas and Shepherd, 2000; Krueger and Carsrud, 1993). Growth is a choice, even though it is often a measure of firm success (Delmar et al., 2003).

\section{Identity and behavior}

Identity is at the root of drivers of behavior (Stryker and Burke, 200o). The personal search for identity can then be considered as a 'family of existential motives' including searches for such fundamental things such as 'meaning, connectedness, empowerment, and even immortality' (e.g., Denhardt, 1987; Fox, 1980; Katz and 
Kahn, 1978; all in Ashforth and Mael, 1989: 22). They define situations by providing an increased sensitivity and receptiveness for behavior cues, therefore providing guidance on how to act (Stryker and Burke, 2000). They can be motivational and aspirational as to their desired identity for the future; identity can serve to support, or debilitate feelings of authenticity, especially in times of transition (Ibarra and Barbulescu, 2010).

Mead (1934, in Stryker and Burke, 2000) situates the study of identity as creating a framework to analyze sociological and social psychological issues, providing a conceptual pathway from identity to behavior. Later, Burke and Reitzes (1981) concluded that the link between identity and behavior was a sense of shared meanings, with Stryker and Burke (200o) eventually proposing an identity theory model: (1) recognizing the identity standard as a 'set of culturally prescribed meanings which are held by the individual to define the role identity in a particular situation' (ibid.: 287), in other words, what is expected, or what should be; (2) taking the perception of meanings in a situation and matching them to the meanings in the identity standard for that situation; (3) acknowledging the mechanisms that provide the comparison between the standard and the perception of the existing; and then (4) concluding with the differences that prompt behaviors to address the differences between the two (Stryker and Burke, 2000).

One of the challenges in holding multiple identities is to recognize that different situations contextually activate different behaviors, as different identities are invoked in different situations (Stryker and Burke, 200o). Which identity takes precedence in determining behavior? Backing up from there, each of us has an internal salience hierarchy which determines which identity takes precedence, as well as precedence in which situation. A particular situation may cause a specific identity to be evoked (Stryker and Burke, 2000).

And then there is the question of identity symmetry, essentially the difference between the actual and the perceived identity. Meister et al. (2014) report that there is actually little research on any positive effects of identity symmetry. However, as lack of that perceived validity can potentially lead to a lack of confidence, including self-questioning, and uncertainty regarding behaviors (Meister et al., 2014), lack of symmetry (internal and external identity alignment) may exacerbate relationship issues, particularly at work.

\section{Identity and confidence}

Within the field of entrepreneurship, confidence (self-assurance stemming from one's trust in one's own abilities) is most often investigated as self-efficacy, 'the conviction that one can successfully execute the behavior required to produce the outcomes' (Bandura, 1977: 193). In Bandura's early specification of this concept, self-efficacy expectations mediate between the person and the behavior, while outcome expectations act between behavior and outcomes (expectation that a specific behavior will lead to certain outcomes) (Bandura, 1977, 1982). As such, self-efficacy 
has the potential to affect both the start and the persistence of a particular behavior (Bandura, 1977).

Over the course of Bandura's work in this area he suggests several relevant components to the theory. First, the dimensions of self-efficacy include magnitude (simple to difficult), generality (circumscribed to more general), and strength (weak to strong) (Bandura, 1977), emphasizing that an assessment of these dimensions must match the precision of the measurement of the efficacy. Second, the four major sources of efficacy information, or the ways one obtains information about one's own capability, are performance accomplishments, vicarious experience, verbal persuasion and emotional arousal (Bandura, 1977). Third, enhanced self-efficacy may be transferable to substantially different activities; however, the most predictable transfers are to more similar activities (Bandura, 1977; Bandura et al., 1969). And finally, one of Bandura's more recent yet less-discussed works includes the consideration of an agentic perspective: 'To be an agent is to influence intentionally one's functioning and life circumstances' (Bandura, 2006: 164).

Self-efficacy primarily entered the field of entrepreneurship through career preference, conceptually interpreted as an interest in becoming an entrepreneur (Scherer et al., 1989; Krueger and Carsrud, 1993; Krueger and Brazeal, 1994), and evolving into consideration of other types of entrepreneurial behaviors (Boyd and Vozikis, 1994; Krueger and Dickson, 1994). The first empirical study of entrepreneurial selfefficacy (Chen et al., 1998) has been followed by a variety of others to further distinguish the task domains (DeNoble et al., 1999; Kickul and D'Intino, 2005; McGee et al., 2009). And a variety of methodological approaches have been used to study self-efficacy differences in numerous areas, with examples including behaviors (Cassar and Friedman, 2009; Smith and Woodworth, 2012; Tumasian and Braun, 2012), country and/or culture (Jung et al., 2001; Urban, 2006; Naktiyok et al., 2010), entrepreneurial education (Peterman and Kennedy, 2003; Karlsson and Moberg, 2013; Piperopoulos and Dimov, 2015) and family business (Carr and Sequeira, 2007; DeNoble et al., 2007). Gender, of course, has also been an important part of self-efficacy studies, and this will be included in the next section of this chapter.

\section{Women's entrepreneurial identity (why it is different for women)}

'A central premise of SIT is that people identify with groups that contribute to a positive sense of self, such as high-status or high-power groups (Ellemers, 1993; Haslam et al., 200o') (Justo et al., Chapter 3 in this volume). The perception of entrepreneurs as traditionally men, independent and risk-takers is mostly a myth, which is perpetuated by the media, our teaching cases, classroom materials, and in general conversation (Bird and Brush, 2002). This role stereotype may fit some entrepreneurs, but not all. Traditional entrepreneurs are thought of in the ideal as those who brilliantly conceive of a new technology innovation, capture a giant market, take a company public and make millions of dollars. These entrepreneurs are financially motivated, take big risks, have networks that are male-dominated, 
and start businesses in traditional product and market sectors, hoping to generate jobs and personal wealth (Kirzner, 1973; Schumpeter, 1935; Delmar et al., 2003; Aldrich et al., 1989; Fairlie and Robb, 2009; Shane and Venkataraman, 200o).

These stereotypes of entrepreneurs being male refer to the traits and behaviors that are culturally deemed appropriate for men and women, and whether these relate to the individual's role or occupation (Heilman, 2001; Meuhlenhard and Peterson, 2011). For example, jobs can become stereotyped as masculine or feminine (Heilman, 1983), and therefore success in these gendered occupations is then believed to require correspondingly stereotypical characteristics (Heilman, 1997). Stereotypical characteristics are quite common as they pertain to dichotomous, visible behaviors typically labelled as 'masculine' and 'feminine' (Gupta and Turban, 2012).

Because of stereotypical beliefs about entrepreneurs as being male/masculine, women entrepreneurs may face competing social identities. Theory suggests that when an individual faces a competing social identity, they will use cultural associations of status-worthiness and competence as cues for self-definition. Thus, given positive associations with masculine entrepreneurial attributes and negative, or at best neutral associations with feminine entrepreneurial attributes (Ahl, 2006; Bruni et al., 2004), entrepreneurs more often identify with masculine characteristics. 'Because of this, and due to the higher status attached to masculine entrepreneurial values, we expect women entrepreneurs to report masculine values, that is, ones that are similar to those of their male counterparts' (Justo et al., Chapter 3 in this volume).

The same is true for aspirations. The very practice of pursuing high-growth entrepreneurship - with its aggressive funding goals and interest in pursuing venture capital funding - has been consistently considered a masculine behavior (Gupta et al., 2009; Gupta and Turban, 2012). Gupta et al. (2009) found that most entrepreneurs, and in particular those who created high-performing, high-growth ventures, are perceived as more stereotypically masculine than feminine.

On the one hand, several scholars have highlighted the importance of women's non-monetary expectations from the business as a key to understand gender differences in business ownership patterns (e.g., MacNabb et al., 1993; Buttner and Moore, 1997; Fenwick and Hutton, 2000; Walker and Brown, 2004). Others, however, have found little gender-based variance in values and attitudes toward success (e.g., Catley and Hamilton, 1998; Kalleberg and Leicht, 1991; Shane et al., 1991). Either way, the general social expectation that entrepreneurs should hold high aspirations for growth may create internal identity conflict for women entrepreneurs who may wish to grow more steadily, slowly, or not at all. In fact, one study of nascent entrepreneurs finds that growth aspirations for men were motivated only by financial success, while women were motivated by status or role, financial success and self-realization (Manolova et al., 2012). 
The general masculinization of the social role of entrepreneurs also influences expectations for behavior. In most Western societies, masculine behaviors are commonly associated with assertiveness and dominance, while feminine behaviors are connected with warmth and emotional expressiveness (Eagly, 1987). Achieving success as an entrepreneur has also been traditionally associated with masculinity (Bird and Brush, 2002; Collins and Moore, 1964; Hisrich and Brush, 1984; Gupta et al., 2009; Gupta and Turban, 2012; Schein, 1975), as successful entrepreneurs have been described as bold, aggressive risk-takers; behaviors that are typically associated with masculinity (Baughn et al., 2006; Gupta and Turban, 2012). Conversely, femininity has not been associated with 'successful' entrepreneurs (Bird and Brush, 2002; Ridgeway, 2001; Rudman and Glick, 2001). Entrepreneurs who exhibit more femininity may not be considered to have the level of competency required for business growth and success (Bird et al., 2012; Cejka and Eagly, 1999). By behaving in a feminine manner, entrepreneurs are likely to perpetuate the perception of societal myths regarding the incompatibility between femininity and venture success.

Not only do masculine stereotypes and identity influence aspirations and behaviors, but these also have an impact on confidence. To be an entrepreneur, one has to believe one has the necessary skills and capabilities to pursue a particular career generally, or to be an entrepreneur (Bandura, 1989; Chen et al., 1998). More specifically, individuals with high entrepreneurial self-efficacy have higher entrepreneurial intentions (Chen et al., 1998; Krueger et al., 2000). Career literature shows that, not surprisingly, women have lower self-efficacy in careers perceived as 'non-traditional', and that societal expectations for women in a particular career shape their self-confidence (Eddleston et al., 2006). As a consequence, women entrepreneurs may have less self-efficacy in performing entrepreneurial tasks such as creating and growing a business, or more specifically, in building a team, seeking resources or interacting with stakeholders (Mueller and Dato-On, 2008).

The next section presents an overview of the chapters in this volume in Part I: Aspirations, Part II: Behaviors and Part III: Confidence.

\section{Part I: Women entrepreneurs, identity and aspirations}

The chapters in Part I explore the relationship between women's entrepreneurial identity and aspirations. Identity theory posits that an individual's personal identity is linked to motivations, goals and aspirations. In other words, how a person selfidentifies, and sees themselves, can motivate them to aspire to a different or new identity.

Chapter 2, 'Developing entrepreneurial identity among start-ups' female founders in high-tech: policy implications from the Chilean case', studies the intersection of various categories of identity by focusing on a particular industry: women entrepreneurs in technology. As such, the authors Katherina Kuschel and Juan-Pablo Labra 
touch on issues related to personal, social and work identities. Building on a relatively thin thread in the entrepreneurship literature, the authors use a social identity framework to investigate identity construction, focusing first on identifying and examining elements that contribute to women building an entrepreneurial identity, and subsequently sharing conclusions on the constraints and obstacles faced during this process. This is a qualitative study, based upon the ubiquitous Berglund (2008) approach in search of theory development. One of the notable questions addressed in this chapter concerns a woman's degree of agency to contribute to the construction of her entrepreneurial identity, particularly within specific social contexts, in this case from an industry perspective, the entrepreneurial ecosystem supporting technological ventures, and geographically: Latin America (largely Chile).

In Chapter 3, 'Perception of success of men and women entrepreneurs: a social identity approach', Rachida Justo, Cristina Cruz and Julio De Castro build from a post-structural feminist view to apply social identity theory (SIT) to explore their contention that for women entrepreneurs, parenthood (especially the presence of dependent children) is a powerful driver of change in an entrepreneur's perceptions of success. The authors' proposition is that the effects of parenthood are stronger for women than for men. One aspect of aspirations that demands more research is the relationship of aspirations to existing measures of entrepreneurial success. This chapter makes four main contributions to the entrepreneurship literature. First, it more firmly connects SIT inside the field of entrepreneurship. Second, it looks at the effect of the work-family interface on shifts in perceptions and values. Third, it expands the measures of entrepreneurial success to include non-monetary measures of success. And fourth, it further disentangles within-gender differences regarding business aspirations in order to better understand the heterogeneity amongst women entrepreneurs.

'Aspirations of women entrepreneurs in poverty: the livelihood entrepreneur', by Smita Trivedi, is Chapter 4. This, our final chapter related to identity and aspirations, presents the consideration of aspirations as quite relative, and unleashes it from any stereotypical assumptions regarding an innate connection between aspirations and opportunity-based entrepreneurship. Trivedi grounds her work in her interest in poverty alleviation to propose a new definition, 'livelihood entrepreneurship'. As such, Trivedi places this concept on a continuum between the concepts of social entrepreneurship and traditional entrepreneurship, recognizing that 'An entrepreneur must first meet her family's basic needs before she can dream about expanding or helping others'. In this chapter, poverty is presented as a multidimensional construct presenting itself as part of economic uncertainty. Further, Trivedi places the concept of community-based enterprise (CBE) as a pathway to sustainable local development (Peredo and Chrisman, 2006), while recognizing the need for a more individual level of analysis and therefore proposing 'livelihood entrepreneurs'. 


\section{Part II: Women, entrepreneurial identity and behavior}

The chapters in Part II connect and explore the relationship between women's social identity and behaviors. It is posited that identity, especially gender identity, influences behaviors. More specifically:

Social identity theory (SIT) is utilized to examine when entrepreneurs are more likely to act consistently with their gender-stereotypic role and when they are more likely to adopt attitudes more congruent with traditional entrepreneurial archetypes. The central assumption underlying social identity theory (Tajfel, 1974, 1978) is that while there are elements of self-identity that are derived from individual traits and interpersonal relationships (personal identity), there are many social settings in which people do not act as independent individuals. (Justo et al., Chapter 3 in this volume)

Part II begins with Chapter 5 by Eliana Crosina, 'On becoming an entrepreneur: unpacking entrepreneurial identity'. Following a brief review of literature on identity and then, more specifically, identity among women entrepreneurs, Crosina compares entrepreneurial identity among professionals and entrepreneurs, then highlights what might be unique or different for women. She notes that the current literature overlooks how entrepreneurial identity forms and evolves. However, there is little consensus on what constitutes entrepreneurial identity, other than it is flexible and requires active 'work'. The chapter offers a framework for entrepreneurial identity construction and includes gender as a key aspect. She argues that for women entrepreneurs, there is a need to gain legitimacy, and to be flexible or 'juggle' their identities based on their multiple roles. The chapter concludes with suggested research directions.

The next chapter in Part II, Chapter 6 by Catherine Elliott and Barbara Orser, 'Feminist entrepreneurial identity: reproducing gender through founder decisionmaking', examines how feminist entrepreneurial identity is expressed through founder decision-making. The authors examine how feminist entrepreneurial identity is expressed through entrepreneurial actions. Beginning with a review of literature that covers adult learning theory, they point out that being female may conflict with one's entrepreneurial self-image. To examine their research question, 15 self-identified 'feminist entrepreneurs' were recruited through Canadian Women's Enterprise Centers. They were interviewed in semi-structured phone calls, where verbatim transcripts were analyzed using an interpretive inductive methodology. Results showed that their feminist entrepreneurial identity was articulated through their acquisition of human and financial resources, strategic compromises, market positioning, governance structures, and relationships. The results yield insight into the gendered nature of venture creation, and in particular, entrepreneurial identity. The investigation yields a conceptual model and future research directions.

The final chapter in Part II, Chapter 7 by Richard Harrison and Claire Leitch, 'Identity and identity work in constructing the woman entrepreneur', examines the organizational context and how the identity construction processes take place. 
Taking a feminist perspective, they ask what is the nature of the identity work undertaken by women in the process of identity formation, identity activation and resultant behavior in an entrepreneurial context. The authors use an ethnographic case study of a female entrepreneur involved in the start-up and growth of her family business. Data collection took place over 18 months and utilized a combination of observation, conversations, interviews and documentary materials. Three overarching themes about identity and identity construction emerged, as well as two others related to gender. The three overarching themes were identity representation, identity construction as an unconscious process, and the influence of life history. For women in particular, the issue of attaining and gaining credibility and issue of invisibility for women in family business were important findings.

\section{Part III: Women, entrepreneurial identity and confidence}

Part III explores the relationship between confidence (self-assurance stemming from trust in one's own abilities), most often studied as self-efficacy, and how this influences the start and persistence of entrepreneurial behaviors (Bandura, 1977). The general masculinization of the social role of the entrepreneur, and characterizations of abilities, influence expectations for behavior.

First is Chapter 8 by Malin Brännback, Shahrokh Nikou, Alan Carsrud and Diana Hechavarria, entitled 'Context, cognition and female entrepreneurial intentions: it is all about perceived behavioral control'. The authors explore the concept of perceived behavioral control, which is a person's subjective belief about their capacity to carry out a task. This subjective belief over the behavior, not the outcome, is significantly influenced by the context of the entrepreneurial activity and the self-efficacy of the individual. For their study, the authors explore family business background and compare male and female entrepreneurs. The study of $2282 \mathrm{stu}-$ dents, representing universities in eight countries, includes previously used reliable measures. Their results show that family business does not influence the subjective belief as to whether women think they will become entrepreneurs, but it does influence whether they think they will succeed in doing so. They find that perceived behavioral control and self-efficacy are distinct concepts, and that their impact is gendered.

The second chapter, Chapter 9 by Magdalena Markowska, 'Motherhood as a springboard for women's entrepreneurial action', examines one form of entrepreneurial identity, 'mumpreneurs', and considers the relationship between becoming entrepreneurial and motherhood. Following Bandura's social learning theory, the author posits that mastery experiences, such as giving birth and raising a child, will have a positive effect on a woman's confidence in general and on entrepreneurial selfefficacy in particular. Specifically, she explores whether or not skills and abilities in child-raising are similar and transferable to entrepreneurial experience. For example, she argues that the budgeting, multi-tasking, persuasive and negotiation skills required for being a mother are similar to those required to be an entrepreneur. 
This theoretical chapter offers a unique perspective - motherhood as a resource which is somewhat contradictory to previous literature which considered motherhood as a cost, or a disadvantage for women starting and growing businesses (Allen et al., 2007).

The third chapter in Part III is Chapter 10, 'Kickstart or jumpstart? Understanding women entrepreneurs' crowdfunding performance', by Smita Srivastava, Pyayt Oo, Arvin Sahaym and Thomas Allison. The authors examine factors that influence women entrepreneurs' seeking funds from crowdfunding lenders through online platforms. They explore the relationship between social identity, passion, self-efficacy and prior business knowledge as this relates to crowdfunding performance. Using data from Kickstarter, a large crowdfunding site, they selected a random sample of female-led projects from three categories - gaming, technology and product design - and analyzed the videos created by these entrepreneurs. Their analysis of 197 projects shows that women entrepreneurs with high self-efficacy will engender more support from potential backers through their strong self-belief. Passion reflects preparedness and commitment, which also influences backers to believe in the entrepreneur's idea.

\section{Conclusion}

We began with a general discussion of the elements of identity, self-concept, social identity and role identity, and how entrepreneurs construct or adopt their entrepreneurial identity during organizational emergence or move into a new organization. We considered how entrepreneurial identity may be distinctive, central or salient, or enduring depending on the context. We argued that entrepreneurial identity is inherently tied to three other key concepts: aspirations, behaviors and confidence. From this general background, we discussed how entrepreneurial identity is different for women, largely because of the historical male participation and association with masculine characteristics and behaviors. Further, the fact that an estimated 90 percent of all research on entrepreneurship focuses on men suggests that much of what we know about entrepreneurial identity is based on studies of men. Given this foundation, we proposed that the linkages between entrepreneurial identity, and aspirations, behaviors and confidence, will shed light on why women will create and grow businesses, how they will grow businesses, and why women are selfassured in creating and growing their businesses.

Our call for papers set forth this premise and the authors included in this volume provide new insights into women's entrepreneurship. But at the same time, new research questions are raised. The chapters examining entrepreneurial identity and aspirations point out that women face contradictions depending on the expectations or norms in an industry, and therefore they may adopt provisional identities (Kuschel and Labra, Chapter 2). In addition, parenthood is experienced differently, which in turn influences personal values as these relate to entrepreneurship (Justo, Cruz and De Castro, Chapter 3). Further, we learned that socio-economic context, 
or a drive for livelihood, also influences identity construction (Trivedi, Chapter 4). Together, these suggest future research questions:

- What is the nature of provisional identities - how are they conceived? Are they shaped to become enduring identities?

- What are the contextual factors that influence provisional identities?

- How does parenthood influence the construction of entrepreneurial identity?

The chapters exploring linkages between entrepreneurial identities and behavior show that women entrepreneurs are motivated to gain legitimacy (Crosina, Chapter 5) and credibility (Harrison and Leitch, Chapter 7). Further, the masculine image of the entrepreneur influences identity construction and representation (Harrison and Leitch, Chapter 7). On the other hand, Elliott and Orser (Chapter 6) suggest that a feminist entrepreneurial identity is manifested by the behaviors of an entrepreneur in acquiring resources and market positioning. These also suggest future research questions:

- Is there a relationship between legitimating or credibility-building behaviors and endurance of entrepreneurial identity over time?

- Is there also a relationship between identity validation (the need for others to recognize the identity) and the degree to which the entrepreneur self-identifies with this role?

- Do women adopting a feminist entrepreneurial identity benefit in resource acquisition behaviors?

Finally, Part III of this book examines the relationship between entrepreneurial identity and confidence. Resource acquisition, in the form of crowdfunding, was significantly related to success in crowdfunding (Srivastava, Oo, Sahaym and Allison, Chapter 10). Brännback, Nikou, Carsrud and Hechavarria (Chapter 8) find gender differences in perceived behavioral control, and confidence in ability to complete tasks associated with entrepreneurship. Markowska (Chapter 9) argues that tasks or behaviors associated with entrepreneurial activity are similar to those gained in child-rearing and motherhood, and should be considered as a resource. Questions for future consideration related to these findings are:

- Is there a difference between male and female entrepreneurs and their entrepreneurial self-efficacy in the venture creation process based on experience in parenting or child-rearing tasks?

- How is perceived behavioral control and self-efficacy similar and different for entrepreneurs in other contexts (for instance, high-technology? Consumer products?)

- What are the educational and training interventions that would support the development of higher levels of entrepreneurial self-efficacy?

While we believe that this volume answers some questions, others raised, like those above, merit continued research, especially recognizing that the question 
of identity overlap at the individual and organizational levels potentially is more salient for business owners than for those who work for organizations owned by others. Continued investigation into entrepreneurial identity will provide us with the knowledge to guide entrepreneurship education, policy recommendations and the practice of entrepreneurship.

\section{References}

Adler, P.A. and P. Adler (1987), Membership Roles in Field Research, Thousand Oaks, CA: SAGE Publications.

Ahl, H. (2006), 'Why research on women entrepreneurs needs new directions', Entrepreneurship Theory and Practice, 30(5), 595-621.

Ajzen, I. (1991), 'The theory of planned behavior', Organizational Behavior and Human Decision Processes, 50(2), 179-211.

Aldrich, H.E., P.R. Reese and P. Dubini (1989), 'Women on the verge of a breakthrough? Networking among entrepreneurs in the United States and Italy', Entrepreneurship and Regional Development, 1, 339-356.

Allen, E., A. Elam, N. Langowitz and M. Dean (2007), 'Report on Women and Entrepreneurship', Global Entrepreneurship Monitor, Wellesley, MA: Babson College.

Ashforth, B.E., G.E. Kreiner and M. Fugate (2000), 'All in a day's work: boundaries and micro role transitions', Academy of Management Review, 25(3), 472-491.

Ashforth, B.E. and F. Mael (1989), 'Social identity theory and the organization', Academy of Management Review, 4(1), 20-39.

Baker, T. and R.E. Nelson (2005), 'Creating something from nothing: resource construction through entrepreneurial bricolage', Administrative Science Quarterly, 50(3), 329-366.

Bandura, A. (1977), 'Self-efficacy: toward a unifying theory of behavioral change', Psychological Review, 84(2), 191.

Bandura, A. (1982), 'Self-efficacy mechanism in human agency', American Psychologist, 37(2), 122-147.

Bandura, A. (1989), 'Regulation of cognitive processes through perceived self-efficacy', Developmental Psychology, 25(5), 729.

Bandura, A. (2006), 'Toward a psychology of human agency', Perspectives on Psychological Science, 1(2), 164-180.

Bandura, A., E.B. Blanchard and B. Ritter (1969), 'Relative efficacy of desensitization and modeling approaches for inducing behavioral, affective, and attitudinal changes', Journal of Personality and Social Psychology, 13(3), 173.

Baughn, C.C., B.L. Chua and K.E. Neupert (2006), 'The normative context for women's participation in entrepreneurship: a multi-country study', Entrepreneurship Theory and Practice, 30, 687-708.

Berglund, K. (2008), 'Discursive diversity in fashioning entrepreneurial identity', Chapter 11 in Chris Steyaert and Daniel Hjorth (eds), Entrepreneurship As Social Change: A Third New Movements in Entrepreneurship Book, Cheltenham, UK and Northampton, MA, USA: Edward Elgar Publishing, pp. 231-250.

Bird, B. and C. Brush (2002), 'A gendered perspective on organizational creation', Entrepreneurship Theory and Practice, 26(3), 41-65.

Bird, B., L. Schjoedt and J.R. Baum (2012), 'Editor's introduction. Entrepreneurs' behavior: elucidation and measurement', Entrepreneurship Theory and Practice, 36(5), 889-913.

Boyd, N.G. and G.S. Vozikis (1994), 'The influence of self-efficacy on the development of entrepreneurial intentions and action', Entrepreneurship Theory and Practice, 18, 63-63. 
Breakwell, G.M. (1988), 'Strategies adopted when identity is threatened', Revue Internationale de Psychologie Sociale, 1, 189-203

Brown, M.E. (1979), 'Identification and some conditions of organizational involvement', Administrative Science Quarterly, 14, 346-355.

Bruni, A., S. Gherardi and B. Poggio (2004), 'Doing gender, doing entrepreneurship: an ethnographic account of intertwined practices', Gender, Work and Organization, 11(4), 406-429.

Brush, C.G. and M. Gale (2014), 'Becoming entrepreneurial: constructing an entrepreneurial identity in an elective entrepreneurship course', in V. Crittenden, K. Esper, N. Karst and R. Slegers (eds), Evolving Entrepreneurial Education: Innovation in the Babson Classroom, Bingley, UK: Emerald Publishing, pp. 305-322.

Burke, P.J. and D.C. Reitzes (1991), 'An identity theory approach to commitment', Social Psychology Quarterly, 54, 239-251.

Buttner, H. and D. Moore (1997), 'Women's organizational exodus to entrepreneurship: self-reported motivations and correlates with success', Journal of Small Business Management, 35(1), 34-46.

Cardon, M.S., J. Wincent, J. Singh and M. Drnovsek (2009), 'The nature and experience of entrepreneurial passion', Academy of Management Review, 34(3), 511-532.

Carlsen, A. (2006), 'Organizational becoming as dialogic imagination of practice: the case of the indomitable Gauls', Organization Science, 17(1), 132-149.

Carr, J.C. and J.M. Sequeira (2007), 'Prior family business exposure as intergenerational influence and entrepreneurial intent: a theory of planned behavior approach', Journal of Business Research, 6o(10), 1090-1098.

Carree, M.A. and A.R. Thurik (2003), 'The impact of entrepreneurship on economic growth', in D.B. Audretsch and Z.J. Acs (eds), Handbook of Entrepreneurship Research, Boston, MA, USA and Dordrecht, the Netherlands: Kluwer Academic Publishers, pp. 437-471.

Cassar, G. (2007), 'Money, money, money: a longitudinal investigation of entrepreneurial career reasons for growth preferences and achieved growth', Entrepreneurship and Regional Development, 19(1), 80-107.

Cassar, G. and H. Friedman (2009), 'Does self-efficacy affect entrepreneurial investment?', Strategic Entrepreneurship Journal, 3(3), 241-260.

Catley, S. and R.T. Hamilton (1998), 'Small business development and gender of owner', Journal of Management Development, 71(1), 75-82.

Cejka, M.A. and A.H. Eagly (1999), 'Gender-stereotypic images of occupations correspond to the sex segregation of employment', Personality and Social Psychology Bulletin, 25(4), 413-423.

Chen, C.C., P.G. Greene and A. Crick (1998), 'Does entrepreneurial self-efficacy distinguish entrepreneurs from managers?', Journal of Business Venturing, 13(4), 295-316.

Chen, X.P., X. Yao and S. Kotha (2009), 'Entrepreneur passion and preparedness in business plan presentations: a persuasion analysis of venture capitalists' funding decisions', Academy of Management Journal, 52(1), 199-214.

Collins, O.F. and D.G. Moore (1964), The Enterprising Man, East Lansing, MI: Michigan State University Press.

Cross, S.E. and H.R. Markus (1994), 'Self-schemas, possible selves, and competent performance', Journal of Educational Psychology, 86(3), 423.

Delmar, F., P. Davidsson and W. Gartner (2003), 'Arriving at the high-growth firm', Journal of Business Venturing, 18(2), 189-216.

Denhardt, R.B. (1987), 'Images of death and slavery in organizational life', Journal of Management, 13, 529-541.

De Noble, A.F., D. Jung and B. Ehrlich (1999), 'Entrepreneurial self-efficacy: the development of a measure and its relationship to entrepreneurial intentions and actions', Entrepreneurship Theory and Practice, 18(4), 63-77.

DeNoble, A., S. Ehrlich and G. Singh (2007), 'Toward the development of a family business self-efficacy scale: a resource-based perspective', Family Business Review, 20(2), 127-140. 
Donnellon, A., S. Ollila and K.W. Middleton (2014), 'Constructing entrepreneurial identity in entrepreneurship education', International Journal of Management Education, 12(3), 490-499.

Douglas, E.J. and D.A. Shepherd (2000), 'Entrepreneurship as a utility maximizing response', Journal of Business Venturing, 15(3), 231-251.

Down, S. and L. Warren (2008), 'Constructing narratives of enterprise: clichés and entrepreneurial selfidentity', International Journal of Entrepreneurial Behavior and Research, 14(1), 4-23.

Downing, S. (2005), 'The social construction of entrepreneurship: narrative and dramatic processes in the coproduction of organizations and identities', Entrepreneurship Theory and Practice, 29(2), 185-204.

Eagly, A.H. (1987), Sex Differences in Social Behavior: A Social-Role Interpretation, Hillsdale, NJ: Erlbaum.

Eddleston, K.A., J.F. Viega and G.N. Powell (2006), 'Explaining sex differences in managerial career satisfiers preferences', Journal of Applied Psychology, 91(2), 437-456.

Edwards, L.-J. and E.J. Muir (2012), 'Evaluating enterprise education: why do it?', Education + Training, $54(4), 278-290$.

Ellemers, N. (1993), 'The influence of socio-structural variables on identity management strategies', European Review of Social Psychology, 4(1), 27-57.

Erogul, M.S. and D. McCrohan (2008), 'Preliminary investigation of Emirati women entrepreneurs in the UAE', African Journal of Business Management, 2(10), 177.

Fairlie, R.W. and A.M. Robb (2009), 'Gender differences in business performance: evidence from the characteristics of business owners survey', Small Business Economics, 33, 375-395.

Farmer, S.M. and K. Kung-Mcintyre (2008), 'Entrepreneur role prototypes and role identity in the US, China, and Taiwan', Academy of Management Proceedings, 2008(1), 1-6.

Farmer, S.M., X. Yao and K. Kung-Mcintyre (2011), 'The behavioral impact of entrepreneur identity aspiration and prior entrepreneurial experience', Entrepreneurship Theory and Practice, 35(2), 245-273.

Fauchart, E. and M. Gruber (2011), 'Darwinians, communitarians, and missionaries: the role of founder identity in entrepreneurship', Academy of Management Journal, 54(5), 935-957.

Fenwick, T. and S. Hutton (2000), 'Women crafting new work: the learning of women entrepreneurs', paper presented at the Adult Education Conference, Vancouver.

Fletcher, D. (2007), “'Toy Story": the narrative world of entrepreneurship and the creation of interpretive communities', Journal of Business Venturing, 22(5), 649-672.

Foss, L. (2004), “'Going against the grain ...", construction of entrepreneurial identity through narratives', in D. Hjorth and C. Steyaert (eds), Narrative and Discursive Approaches in Entrepreneurship, Cheltenham, UK and Northampton, MA, USA: Edward Elgar Publishing, pp. 80-104.

Fox, A. (1980), 'The meaning of work', in G. Esland and G. Salaman (eds), The Politics of Work and Occupations, Toronto: University of Toronto Press, pp.139-191.

Gartner, W.B. and C.G. Brush (2007), 'Entrepreneurship as organizing: emergence, newness and transformation', in M. Minitt (ed.), Entrepreneurship, Santa Barbara, CA: Praeger Publishing, pp. 1-2o.

Gill, R. and G.S. Larson (2014), 'Making the ideal (local) entrepreneur: place and the regional development of high-tech entrepreneurial identity', Human Relations, 67(5), 519-542.

Gupta, V.K. and D. Turban (2012), 'Evaluation of new business ideas: do gender stereotypes play a role?', Journal of Managerial Issues, 24(2), 140-156.

Gupta, V.K., D. Turban, S.A. Wasti and A. Sikdar (2009), 'The role of gender stereotypes in perceptions of entrepreneurs and intentions to become an entrepreneur', Entrepreneurship Theory and Practice, 33(2), 397-417.

Hall, D.T. 2002. Careers In and Out of Organizations. Los Angeles, CA: SAGE Publications.

Hall, D.T., B. Schneider and H.T. Nygren (1970), 'Personal factors in organizational identification', Administrative Science Quarterly, 176-190.

Haslam, S.A., C. Powell and J. Turner (200o), 'Social identity, self-categorization, and work motivation: 
rethinking the contribution of the group to positive and sustainable organisational outcomes', Applied Psychology, 49(3), 319-339.

Heilman, M.E. (1983), 'Sex bias in work settings: the lack of fit model', Research in Organizational Behavior, 5, 269-298.

Heilman, M.E. (1997), 'Sex discrimination and the affirmative action remedy: the role of sex stereotypes', Journal of Business Ethics, 16(9), 877-889.

Heilman, M.E. (2001), 'Description and prescription: how gender stereotypes prevent women's nascent up the organizational ladder', Journal of Social Issues, 51(4), 657-674.

Hessels, J., M. Van Gelderen and R. Thurik (2008), 'Entrepreneurial aspirations motivations, and their drivers', Small Business Economics, 31(3), 323-339.

Hisrich, R. and C. Brush (1984), 'The woman entrepreneur: management skills and business problems', Journal of Small Business Management, 22(1), 30-37.

Hoang, H. and J. Gimeno (2010), 'Becoming a founder: how founder role identity affects entrepreneurial transitions and persistence in founding', Journal of Business Venturing, 25(1), 41-53.

Hogg, M.A. and D. Abrams (1988), Social Identification: A Social Psychology of Intergroup Relations and Group Processes, London: Routledge.

Hogg, M.A., D.J. Terry and K.M. White (1995), 'A tale of two theories: a critical comparison of identity theory with social identity theory', Social Psychology Quarterly, 58(4), 255-269.

Hytti, U. and J. Heinonen (2013), 'Heroic and humane entrepreneurs: identity work in entrepreneurship education', Education + Training, 55(8/9), 886-898.

Ibarra, H. (1999), 'Provisional selves: experimenting with image and identity in professional adaptation', Administrative Science Quarterly, 44(4), 764-791.

Ibarra, H. and R. Barbulescu (2010), 'Identity as narrative: prevalence, effectiveness, and consequences of narrative identity work in macro work role transitions', Academy of Management Review, 35(1), 135-154.

Jain, S., G. George and M. Maltarich (2009), 'Academics or entrepreneurs? Investigating role identity modification of university scientists involved in commercialization activity', Research Policy, 38(6), 922-935.

Jennings, J.E. and C.G. Brush (2013), 'Research on women entrepreneurs: challenges to (and from) the broader entrepreneurship literature?', Academy of Management Annals, 7(1), 663-715.

Johansson, A.W. (2004), 'Narrating the entrepreneur', International Small Business Journal, 22(3), 273-293.

Jones, R., J. Latham and M. Betta (2008), 'Narrative construction of the social entrepreneurial identity', International Journal of Entrepreneurial Behavior and Research, 14(5), 330-345.

Jung, D.I., S.B. Ehrlich, A.F. De Noble and K.B. Baik (2001), 'Entrepreneurial self-efficacy and its relationship to entrepreneurial action: a comparative study between the US and Korea', Management International, 6(1), 41.

Kalleberg, A.L. and K.T. Leicht (1991), 'Gender and organizational performance: determinants of small business survival and success', Academy of Management Journal, 34(1), 136-161.

Karlsson, T. and K. Moberg (2013), 'Improving perceived entrepreneurial abilities through education: exploratory testing of an entrepreneurial self efficacy scale in a pre-post setting', International Journal of Management Education, 11(1), 1-11.

Katz, D. and R.L. Kahn (1978), The Social Psychology of Organization, 2nd edn, New York: Wiley.

Kickul, J. and R.S. D'Intino (2005), 'Measure for measure: modeling entrepreneurial self-efficacy onto instrumental tasks within the new venture creation process', New England Journal of Entrepreneurship, 8(2), 6.

Kikooma, J.F. (2011), 'Negotiating enterprising identities: African woman entrepreneur stories of challenge, perseverance and triumph', China-USA Business Review, 10(7), 573-586.

Kirzner, I.M. (1973), Competition and Entrepreneurship, Chicago, IL: University of Chicago Press

Kolvereid, L. (1992), 'Growth aspirations among Norwegian entrepreneurs', Journal of Business Venturing, 7(3), 209-222. 
Kreiner, G.E., E. Hollensbe, M.L. Sheep, B.R. Smith and N. Kataria (2015), 'Elasticity and the dialectic tensions of organizational identity: how can we hold together while we are pulling apart?', Academy of Management Journal, 58(4), 981-1011.

Krueger, N.F. and D.V. Brazeal (1994), 'Entrepreneurial potential and potential entrepreneurs', Entrepreneurship Theory and Practice, 18, 91-91.

Krueger, Norris F. and Alan L. Carsrud (1993), 'Entrepreneurs intentions, applying the theory of planned behavior', Entrepreneurship and Regional Development, 5(4), 315-330.

Krueger, N. and P.R. Dickson (1994), 'How believing in ourselves increases risk taking: perceived selfefficacy and opportunity recognition', Decision Sciences, 25(3), 385-400.

Krueger, N.F., M.D., Reilly and A.L. Carsrud (2000), 'Competing models of entrepreneurial intentions', Journal of Business Venturing, 15(5), 411-432

Lee, S.M. (1971), 'An empirical analysis of organizational identification', Academy of Management Journal, 14, 213-226.

Light, P.C. (2005), 'Searching for social entrepreneurs: who they might be, where they might be found, what they do', draft presented at the Conference of the Association for Research on Nonprofit and Voluntary Organizations, November.

Lindgren, M. and J. Packendorff (2008), 'Woman, teacher, entrepreneur: on identity construction in female entrepreneurs of Swedish independent schools', in I. Aaltio, P. Kyro and E. Sundin (eds), Women Entrepreneurship and Social Capital, Copenhagen: Copenhagen Business School Press, pp. 193-223.

Manolova, T., C. Brush, L. Edelman and K. Shaver (2012), 'One size does not fit all: entrepreneurial expectancies and growth intentions of US women and men nascent entrepreneurs', Entrepreneurship Theory and Practice, 24(1-2), 7-27.

Marková, H.R. (1987), 'In the interaction of opposites in psychological processes', Journal for the Theory of Social Behavior, 17, 279-299.

Markus, H. and P. Nurius (1986), 'Possible selves', American Psychologist, 41(9), 954.

McAdams, D.P. (1999), 'Personal narratives and the life story', in L. Pervin and O. John (eds), Handbook of Personality: Theory and Research, 2nd edn, New York: Guilford Press, pp. 478-50o.

McCall, G.J. and J.L. Simmons (1978), Identities and Interactions: An Examination of Human Associations in Everyday Life, rev. edn, New York: Free Press

McGee, J.E., M. Peterson, S.L. Mueller and J.M. Sequeira (2009), 'Entrepreneurial self-efficacy: refining the measure', Entrepreneurship Theory and Practice, 33(4), 965-988.

MacNabb, A., J. McCoy, P. Weinreich and M. Northover (1993), 'Using identity structure analysis (ISA) to investigate female entrepreneurship', Entrepreneurship and Regional Development, 5(4), 301-313.

Mead, G.H. (1934), Mind, Self and Society, Chicago, IL: University of Chicago Press.

Meister, A., K.A. Jehn and S.M.B. Thatcher (2014), 'Feeling misidentified: the consequences of internal identity asymmetries for individuals at work', Academy of Management Review, 39(4), 488-512.

Merton, R.K. (1957), 'The role-set: problems in sociological theory', British Journal of Sociology, 8(2), 106-120.

Miller, D., L. Breton-Miller and R.H. Lester (2011), 'Family and lone founder ownership and strategic behaviour: social context, identity, and institutional logics', Journal of Management Studies, 48(1), $1-25$.

Muehlenhard, C.L. and Z.D. Peterson (2011), 'Distinguishing between sex and gender: history, current conceptualization and implications', Sex Roles, 64(11), 791-803.

Mueller, S. and M.C. Dato-On (2008), 'Gender-role orientation as a determinant of entrepreneurial selfefficacy', Journal of Developmental Entrepreneurship, 13(1), 3-20.

Murnieks, C.Y., E. Mosakowski and M.S. Cardon (2014), 'Pathways of passion identity centrality, passion, and behavior among entrepreneurs', Journal of Management, 40(6), 1583-1606.

Naktiyok, A., C.N. Karabey and A.C. Gulluce (2010), 'Entrepreneurial self-efficacy and entrepreneur- 
ial intention: the Turkish case', International Entrepreneurship and Management Journal, 6(4), 419-435.

Neck, H., C. Brush and E. Allen (2009), 'The landscape of social entrepreneurship', Business Horizons, 52, 13-19.

Nel, P., A. Martiz and O. Thongprovati (2010), 'Motherhood and entrepreneurship: the mumpreneur phenomenon', International Journal of Organizational Innovation, 3(1), 6-34.

Peredo, A.M. and J.J. Chrisman (2006), 'Toward a theory of community-based enterprise', Academy of management Review, 31(2), 309-328.

Peterman, N.E. and J. Kennedy (2003), 'Enterprise education: influencing students' perceptions of entrepreneurship', Entrepreneurship Theory and Practice, 28(2), 129-144.

Phillips, N., P. Tracey and N. Karra (2013), 'Building entrepreneurial tie portfolios through strategic homophily: the role of narrative identity work in venture creation and early growth', Journal of Business Venturing, 28(1), 134-150.

Piperopoulos, P. and D. Dimov (2015), 'Burst bubbles or build steam? Entrepreneurship education, entrepreneurial self-efficacy, and entrepreneurial intentions', Journal of Small Business Management, 53(4), 970-985.

Ridgeway, C. (2001), 'Gender, status, and leadership', Journal of Social Issues, 57(4), 637-655.

Rudman, L. and P. Glick (2001), 'Prescriptive gender stereotypes and backlash toward agentic women', Journal of Social Issues, 57(4), 743-762.

Schein, V.E. (1975), 'Relationships between sex role stereotypes and requisite management characteristics among female managers', Journal of Applied Psychology, 6o(3), 340-344.

Scherer, R.F., J.S. Adams, S. Carley and F.A. Wiebe (1989), 'Role model performance effects on development of entrepreneurial career preference', Entrepreneurship Theory and Practice, 13, 53-81.

Schneider, B., D.T. Hall and H.T. Nygren (1971), 'Self image and job characteristics as correlates of changing organizational identification', Human Relations, 24(5), 397-416.

Schumpeter, J. (1935), The Theory of Economic Development, New York: Oxford University Press.

Shane, S., L. Kolvereid and P. Westhead (1991), 'An exploratory examination of the reasons leading to new firm formation across country and gender', Journal of Business Venturing, Special International Issue, 6(6), 431-446.

Shane, S. and S. Venkataraman (2000), 'The promise of entrepreneurship as a field of research', Academy of Management Review, 25(1), 217-236.

Shaver, K.G., N.M. Carter, W.B. Gartner and P.D. Reynolds (2001), 'Who is a nascent entrepreneur? Decision rules for identifying and selecting entrepreneurs in the Panel Study of Entrepreneurial Dynamics (PSED)', Technical Paper, Jönköping International School of Business, Jönköping.

Shepherd, D. and J.M. Haynie (2009), 'Birds of a feather don't always flock together: identity management in entrepreneurship', Journal of Business Venturing, 24, 316-337.

Smith, I.H. and W.P. Woodworth (2012), 'Developing social entrepreneurs and social innovators: a social identity and self-efficacy approach', Academy of Management Learning and Education, 11(3), $390-407$.

Stanworth, M.J.K. and J. Curran (1976), 'Growth and the small firm - an alternative view', Journal of Management Studies, 13(2), 95-110.

Stryker, S. (1980), Symbolic Interactionism: A Social Structural Version, Menlo Park, CA: Benjamin/ Cummings Publishing Company.

Stryker, S. (1987), 'Identity theory: developments and extensions', in Krysia Yardley and Terry Honess (eds), Self and Identity: Psychosocial Perspectives, London: Wiley, pp. 89-104.

Stryker, S. and P.J. Burke (200o), 'The past, present, and future of an identity theory', Social Psychology Quarterly, 63, 284-297.

Stryker, S. and R.T. Serpe (2012), 'Commitment, identity salience, and role behavior: theory and research example', in W. Ickes and E.S. Knowles (eds), Personality, Roles, and Social Behavior, New York: Springer, pp. 199-218. 
Stryker, S. and A. Stratham (1985), 'Symbolic interaction and role theory', in I.G. Lindzey and E. Aronson (eds), Handbook of Social Psychology, New York: Random House, pp. 311-378.

Sveningsson, S. and M. Alvesson (2003), 'Managing managerial identities: organizational fragmentation, discourse and identity struggle', Human Relations, 56(10), 1163-1193.

Tajfel, H. (1974), 'Social identity and intergroup behaviour', Information (International Social Science Council), 13(2), 65-93.

Tajfel, H.E. (1978), Differentiation between Social Groups: Studies in the Social Psychology of Intergroup Relations, London: Academic Press.

Tajfel, H. (1982), 'Social psychology of intergroup relations', Annual Review of Psychology, 33(1), 1-39.

Tajfel, H. and J.C. Turner (1979), 'An integrative theory of intergroup conflict' Social Psychology of Intergroup Relations, 33(47), 74.

Tajfel, H. and J.C. Turner (1986), 'The social identity theory of intergroup behavior', in W.G. Austin and S. Worchel (eds), Psychology of Intergroup Relations, 2nd edn, Chicago, IL: Nelson-Hall, pp. 7-24.

Tumasian, A. and R. Braun (2012), 'In the eye of the beholder: how regulatory focus and self-efficacy interact in influencing opportunity recognition', Journal of Business Venturing, 27(6), 622-636.

Turner, J.C. (1985), 'Social categorization and the self-concept: a social cognitive theory of group behavior', in E.J. Lawler (ed.), Advances in Group Processes, Vol. 2, Greenwich, CT: JAI Press, pp. 77-122.

Urban, B. (2006), 'Entrepreneurship in the rainbow nation: effect of cultural values and ESE on intentions', Journal of Developmental Entrepreneurship, 11(3), 171-186.

Vanevenhoven, J. and E. Liguori (2013), 'The impact of entrepreneurship education: introducing the entrepreneurship education project', Journal of Small Business Management, 51(3), 315-328.

Verheul, I., L. Uhlaner and R. Thurik (2005), 'Business accomplishments, gender and entrepreneurial self-image', Journal of Business Venturing, 20(4), 483-518.

Vesala, K., J. Peura and G. McElwee (2007), 'The split entrepreneurial identity of the farmer', Journal of Small Business and Enterprise Development, 14(1), 48-63.

Vesalainen, J. and T. Pihkala (200o), 'Entrepreneurial identity, intentions and the effect of the pushfactor', International Journal of Entrepreneurship, 4, 105.

Vesper, K.H. (1999), 'Unfinished business (entrepreneurship) of the 2oth century', paper presented at USASBE conference, San Diego, CA, January.

Vignoles, V.L., C. Regalia, C. Manzi, J. Golledge and E. Scabini (2006), 'Beyond self-esteem: influence of multiple motives on identity construction', Journal of Personality and Social Psychology, 90(2), 308.

Walker, E. and A. Brown (2004), 'What success factors are important to small business owners?', International Small Business Journal, 22(6), 577-594.

Warren, L. (2004), 'Negotiating entrepreneurial identity: communities of practice and changing discourses', International Journal of Entrepreneurship and Innovation, 5(1), 25-35.

Watson, T.J. (2009), 'Entrepreneurial action, identity work and the use of multiple discursive resources the case of a rapidly changing family business', International Small Business Journal, 27(3), 251-274.

Westhead, P. and M. Wright (1998), 'Novice, portfolio, and serial founders: are they different?', Journal of Business Venturing, 13(3), 173-204.

Woo, C.Y., A.C. Cooper and W.C. Dunkelberg (1991), 'The development and interpretation of entrepreneurial typologies', Journal of Business Venturing, 6(2), 93-114.

Woolf, V. (1992), The Waves. In Collected Novels of Virginia Woolf, London: Palgrave Macmillan, pp. $335-508$. 